\title{
The Theory of Agricultural Price Bubble \& Price Crash in Global Economy
}

\author{
M.B. Dastagiri ${ }^{1}$, L. Bhavigna ${ }^{2}$ \\ ${ }^{1}$ Principal Scientist, ICAR-National Academy of Agricultural Research Management, Rajendranagar, \\ Hyderabad-500030. India \\ ${ }^{2}$ Young Professional-II, ICAR-NAARM, Rajendranagar, Hyderabad-500030, India \\ Correspondence: M. B. Dastagiri, Principal Scientist, ICAR-National Academy of Agricultural Research Management, \\ Rajendranagar, Hyderabad-500030. India.
}

\author{
Received: July 22, $2019 \quad$ Accepted: August 12, $2019 \quad$ Available online: August 21, 2019 \\ doi:10.11114/aef.v6i5.4464 URL: https://doi.org/10.11114/aef.v6i5.4464
}

\begin{abstract}
Agricultural prices play greater role in living Economics. Since many decades' farmers faced declining agricultural prices and low prices in developing countries. Therefore, in these countries agricultural price policies are under closer appraisal. Government and policy makers worry about inflation. Economic precision is required in determining prices. This understanding led to conception of the study. The specific objectives are to review various agricultural price theories, research evidences and construct the theory of agricultural price bubble and crash and their effect on macro economy and suggest measures to improve. The study reviews various agricultural price theories, concepts, policies, research gaps and do meta-analysis and formulated the theory of Agricultural prices bubble and price crash. Since 1950, many development economists and practitioners prophesy in developing countries is that low agricultural commodities prices discourage poverty alleviation. Many countries are unable to make successful pricing policies due to there is not enough operative methodological and theoretical support for decision-making. According to the economic theory of cooperativism, the entities come closer to the pecking order theory. Unexpected changes and changes in regulations can have significant impact on the profitability of farming activities. "Demand channel" is the crucial factor in elucidation of commodity price growth. Future prices moments in agriculture have fat-tailed distributions and display quick and unpredicted price jumps. World Trade Organization study highlights the importance of strengthening multilateral disciplines on both import and export trade interventions to food price fluctuations to reduce beggar-thy-neighbor unilateral trade policy. The theory of NAFTA regionalism did not lead to regionalization and not increasing share of intraregional international trade. In EU countries land rents in modern agriculture causing upward trend in agricultural land prices. Information friction, agricultural supports, agricultural price \& trade policies, agricultural price transmission are responsible price fluctuations. In economic theory, asymmetric price transmission has been the subject of considerable attention in agricultural gaps. Selection of forecasting models are based on chaos theory. Chaos in agricultural wholesale price data provides a good theoretical basis for selecting forecasting models. This theory can be applied to agricultural prices forecasting. Novelties in agricultural products fluctuations research offer scientific basis in planning of agricultural production.
\end{abstract}

Keywords: agricultural price theory, weaknesses, research gaps and new theory formulation

\section{Introduction}

Globally, prices decide the fate of agriculture and farmer. Agricultural prices play greater role in living Economics. Especially, developing countries farmer model is a vicious circle of traps, which involves livelihood, poverty and debt traps leading to farmer's suicides. For last 50 years, declining prices and last 20 years, low prices were faced by developing countries farmers. Changes in LDC agriculture due to LPG in 1990's were not just confined to changes in relative prices and altered the allocation of resources within and among markets.

The WTO contributes food security to certain extent by efficient production and distribution of food supply. Since 1950, policy makers and development economist's advocacy is that low agricultural prices reduce poverty in developing countries as in these nations major share of household income is from agriculture (Aksoy and Beghin 2004). Similarly, Hertel and Winters 2006 reported that higher agricultural prices adversely affect the poorest people and poverty 
reduction in developing countries.

Food prices can distress farmers adversely by affecting their affordability, farm returns and labor demand in agriculture. The studies on trade and development assumed that in low income countries, high food prices bad for poor and rural people due to as they are net food buyers (Ravallion, 1990). Studies by Ivanic and Martin (2008) and World Bank (2008), reported that based on household data food price hikes in 2008 have pushed worldwide additionally 100 million poor in to poverty. The trade flows and competitiveness between producing and exporting countries influenced by change in policies by Satyanarayana.V, Wilson.WW, Johnson.DD, Dooley.FJ (1998).

Financial dictionary, 2012 defines world price as a price for any identified good or service in all other countries than its own. In general, international prices influenced by world prices. Encyclopedia, 2010 reported that under modern capitalism commercial exports and imports takes place at world prices. Financial dictionary, 2012 declared that any country exports goods and services when local prices are lower than world prices and imports goods and services when local prices higher than the world prices.

The literature on agricultural commodities exports and imports growth and instability shows that as: David Hallam, 2003 reported that most of the agricultural commodities have inelastic demand leading to lower world prices and lower export earnings for developing countries. In general export instability more in LDC's than in DC's but it causes more negative effect on economic growth in LDC's than DC's (Glezakos, (1973). Nurkse (1958) and Caine (1958), Chaudhary and Qaisrani, 2002 reported that economic growth badly effected by export instability.

In Indian context, a study by UNCTAD (2009) concluded that Indian exports are highly responsive to world income changes and found that $1 \%$ decline world GDP will reduce $1.88 \%$ of India's exports. India's exports have experienced instability in the developing countries; Singh and Sangla (2012). A study by Upender (2007) found that in India export and import prices have long run as well short run relationship.

Existing price supporting mechanisms in the countries could not immune farmers with economic losses, hence necessitating a new approach. Either researchers, policy makers, governments or think tank institutes are unable to capture the prices, their transmission and suggest the effect of agricultural prices on production, inflation, poverty and farmer's welfare. Government and policy makers worry about inflation. Market players are under high risk with volatility of prices. Existing research could not aptly capture enough, these changes, to immune farmer of price woes and consumer affordability. Prices are a complex phenomenon. A cob web model is inherent in agricultural sector. Agriculture price policy plays an important role in economic development. It acts as a crucial instrument in incentivizing farmers as prices affect their income and consumption. Governments have decided to protect the farmers by taking oath to double farmer's income which essentially involves innovative agriculture price policy. Of late in many developing countries Agricultural price policies are under closer review. Economic precision is required in determining prices. This understanding led to conception of the study.

\section{Objectives}

1. To review various Agricultural price theories in developing Countries

2. To find out research gaps and weakness in Agricultural prices theories and markets

3. To study the macro economic effects of price bubble and price crash on various sectors of the economy

4. To formulate the new Agricultural price theories, polices, measure for developing countries agriculture.

\section{Methodology}

This is basically theoretical frame work of Agricultural prices. The study reviews various agricultural price theories, concepts, policies, research gaps and do meta-analysis and then formulated the theory of Agricultural prices bubble and price crash. Finally, the study suggests suitable price fixing mechanisms, policies, strategies, measures for the prosperity of developing countries agricultural development. The study uses Delphi research method to validates the results.

\section{Results and Discussions}

\subsection{Review on Agricultural Price Theory}

Rechka Kateryna (2018) stated that ineffective methodological and theoretical pricing process in agribusiness leading to miscalculation in pricing in agribusiness often lead to great loss. Mateos-Ronco Alicia, Guzman-Asuncion Sandra (2018) stated that according to the economic theory of cooperativism, the entities come closer to the pecking order theory. Novickyte Lina (2018) mentioned that unexpected changes in agriculture policy that affect producers' activities. Changes in regulations also have significant impact on the profitability of farming activities. Xie Chaoping, Gao Jianfeng, Grant Jason H, Anders Sven (2018) stated that the "new-new" trade theory focus has changed international economic research to firms of heterogeneous and the margins which are basis for participation in international trade. Lloyd Tim (Feb 2017) stated that in many countries, producers and consumers face problems because of change in food industry prices which is major source. 
The correlation between observed price spikes and bubble is low. But most of the time price explosiveness happened during downward price moments reported by Etienne Xiaoli L, Irwin Scott H, Garcia Philip (Jan 2015). Landgraf Steven, Chowdhury Abdur (2015) stated that a large part "demand channel" explains price growth. Some researchers reported that mid-2000s world commodity price "bubble" happened because past decade rapid industrial growth.

Simonovska Ana, Gjosevski Dragan, Campos Monica (Dec 2014) reported that without liquidity constraints farm companies follow 'pecking-order' pattern and farm companies with liquidity-constrained follow more 'trade-off' theory. Hajdukiewicz Agnieszka (Jun 2014), reported that the economic theory suggests that producer can compete in the market by registering Protected Designation of Origin (PDO) / Protected Geographical Indication (PGI) / Traditional Speciality Guarantied (TSG). Zafeiriou Eleni, Sariannidis Nikolaos (Apr 2011), found that as per the "Theory of Storage", agricultural commodities complex future price behavior is as result of interaction of factors between inventories and other financial resources. Isgin Tamer, Forster D Lynn (Sep 2006) deliberated on "real option pricing theory" which states that urban peripheral farm land values would increase because of nearby urban development. Koekebakker S, Lien G (Nov 2004) predicted that in agricultural futures price movements have fat-tailed distributions and exhibit sudden and unpredicted price jumps. The volatility of futures prices is time-dependent both as a function of seasonal effect and time to maturity.

\subsection{Research on Agricultural Prices}

Chand, 2005; reported that Indian agricultural trade directly affected by low level of international prices. Giri et.al, 2011 concluded that transmitted the volatile international market can affect the domestic economy, the prices of food grains and food entitlement of the poor. Dastagiri and Vajrala in 2018 found that global agricultural supports significantly impacted the world market prices. Dastagiri and Vajrala 2018, reported that the political economy of protecting producer and consumer depends upon their share of votes in elections.

Luckstead.J, Devadoss.S (May 2019) found that cumulative prospect theory predicts farmer's coverage decisions accurately at 70\% if insurance is framed as an investment. Ricci Elena Claire, Peri Massimo, Baldi, Lucia (Feb 2019) observed that farmers are price takers in the pasta chain. Mitchell Tara (Oct 2017) found that producers receive more prices from middlemen if they have access to information about market prices. Xie Hualin, Wang Bohao (Jun 2017) found that in China grain production affected by fluctuations of agricultural product prices and their long-term equilibrium relationship.

Li Jian, Li Chongguang, Chavas Jean-Paul (Mar 2017) showed that in China high self-sufficiency commodities markets viz; wheat and corn were less experienced speculative bubble but not in the case of low self-sufficiency commodities (soybean). The difference is attributed to market intelligence, Chinese agricultural trade and government policies. A study by Li Jian, Chavas Jean-Paul, Etienne Xiaoli L, Li Chongguang (2017) on macroeconomic determinants of bubbles conclude that macroeconomic factors have asymmetric effects on bubbles. Economic growth, money supply, and inflation have positive effects on price bubbles and interest rates negatively affect the likelihood of bubbles. Anderson Kym (Oct 2016) revealed that over the past two to three decades' agricultural price and trade policies were causing disarray in world food markets and these are responsible distortion in agricultural incentives in both highincome and developing countries. Pieters Hannah, Swinnen Johan (May 2016) proved that contrary to theoretical findings they proved that in short run government interventions in several countries reduce price volatility in domestic market.

For farmers and policy makers, modelling accurately extreme risk in returns due to volatility in agricultural prices utmost important, reported by Gong Xue, Sriboonchitta Songsak, Rahman Sanzidur, Kuson Siwarat (May 2015). Thennakoon Jayanthi, Anderson Kym (Jan 2015) reported that on the proposal submitted by developing countries agricultural Special Safeguard Mechanism (SSM) in the World Trade Organization, the study highlights the importance of strengthening multilateral disciplines on both import and export trade interventions to food price fluctuations to reduce beggar-thy-neighbor unilateral trade policy. Nureev Rustem M, Petrakov Pavel K (2015) concluded that developed feudalism is the result of contradictions exchange of agricultural products to urban goods and services. He suggested that under these conditions, the development of the problem of "fair price" is inevitable. Zambersky Pavel, Cajka Radek (2015) mentioned that there are many problems with implementing trade policy and empirical case studies have shown the objectives of the policy were not accomplished. Czyzewski Bazyli, Brelik Agnieszka (Dec 2014), reported that in EU countries prevalence of land rents in modern agriculture causing long-lasting upward trend in agricultural land prices.

Selection of forecasting models are based on chaos theory. Chaos in agricultural chaos in wholesale price data provides a good theoretical basis for selecting forecasting models. This theory can be applied to agricultural prices forecasting. Su Xin, Wang Yi, Duan Shengsen, Ma Junhai (Dec 2014). Allen Treb (Nov 2014) showed that introducing information frictions reconciles the theory with the observed patterns in the data. And roughly half the observed regional price dispersion is due to information frictions. Gilbert Christopher L, Pfuderer Simone (Jun 2014) suggested that food and 
non-food commodities must be linked to avoid spillover effects on latter.

Though developing countries have comparative advantage in biofuels, they were unable to benefit because of sudden increase in commodity prices De Gorter Harry, Drabik Dusan, David R. Just (Jul 2013). Dorward Andrew (Apr 2013) reported that current policy overlooked the real food price changes because of non-availability of pertinent and accessible indicators for real food prices and monitoring agricultural productivity sustainability. De Castro Eduardo Rodrigues, Teixeira Erly Cardoso (May 2012) concluded that in short run, except wheat, others own output supply response is inelastic. Hence wheat behaves elastic response to price. Mitra Sophie, Boussard Jean-Marc (Jan 2012) stated that storage causes endogenous volatility of prices by making chaotic dynamics. Its effect on price variations are mixed.

The power of transport costs significant, spatially distributed supply and process create oligopsony on agricultural markets discussed by Graubner Marten, Balmann Alfons, Sexton Richard J (Jul 2011). Rezitis Anthony N, Stavropoulos Konstantinos S (May 2011) conclude that price volatility is a major significant risk factor in Greek meat production. Severova Lucie, Sredl Karel (Sep 2010) although a substantial part of agriculture production arises outside of the oligopolistic structures, trade in these products mainly occurs within oligopolistic sectors. Agricultural dramatic swings, stringent quality requirement, GMF crops debate, latest environmental regulations, climatic disastrous, energy crops demand, Europe Common Agricultural Policies and financial crisis are the future threats and potential challenges, by Darnhofer Ika, Bellon Stephane, Dedieu Benoit, Milestad Rebecka (Jul-Sep 2010).

Palma Lampreia Dos Santos Maria Jose et. al, (2010) concluded that in spite of European small farmers have great potential of innovations because of CAP's but their innovation capacity would be curtailed in future by water supply, irrigation prices, agricultural credit access. Chao Sun, Jun Meng (Oct 2009) reported that agricultural product prices are complex and influenced by various factors. Hence innovative price fluctuation research is scientific basis for agricultural production planning. Can Muharrem (Jul-Dec 2008) found that the formation of market and prices is different than other goods and services: supply may change from year to year even longer period. Meyer J, von Cramon-Taubadel S (Nov 2004) reported that in economic theory, asymmetric price transmission has been the subject of considerable attention in agricultural gaps. Some of the econometric tools that are applied for study of asymmetry agricultural prices are such as momentum-threshold autoregression (M-TAR) used by Ghosray (2008) in study of rice pricing, and Adammer et al (2012) in discussing speculative bubbles. Miljkovic D, Paul R (Sep 2003) study finds that due to CUSTA, only trade creation occurs USA agricultural exports to Canada. This confirms that the theory of NAFTA regionalism did not lead to regionalization and in turn not increasing share of intraregional international trade.

\subsection{Agricultural Price Theory and Macro-Economic Effects on Global Countries Economy}

The macro economic effects of tangible and non-tangible effects of price bubble and price crash on various countries of the economy shown in Table 1. The study found that Agricultural prices are complex phenomena and effects on many sectors of the economy. It is a subject of hunger and contrasting to general economic principles. The price bubbles benefits farmers but it affects many multistake holders like consumers, poor, BPL people, politicians, budget of the economy, WTO commitments, inflation, market players under risk, food entitlement and food security. Contrastingly, Price crash will effect farmers badly and force them to undergo deferent traps and commit suicide. It also leads to agrarian crisis in tropical countries.

The government plays greater role to balance price crash by various schemes, programs, subsidies, MSP and by implementing UBI. It also protects farmers by various policies like different insurances, direct payments, cyclic payments, export and import subsidies etc.

The Theory of Agricultural Price Bubble \& Price Crash on macro-economic effects of global countries.

\begin{tabular}{|l}
$>$ A cob web model is inherent in agricultural price theory. \\
$>$ Globally, prices decide the fate of agriculture and farmer. \\
$>$ Agricultural prices play greater role in living Economics. \\
$>$ Economic precision is required
\end{tabular}


Table 1. The Theory of Agricultural Price Bubble \& Price Crash on macro-economic effects of global countries.

\begin{tabular}{|c|c|c|c|}
\hline $\begin{array}{l}\text { S. } \\
\text { No }\end{array}$ & Item & Effects on Farmers & Effects on Multistake-holders \\
\hline $\mathrm{I}$ & Price Bubble/ Inflation & Farmers are benefited & $\begin{aligned}> & \text { Consumers negatively effected } \\
> & \text { BPL People (purchasing power), Anti } \\
& \text { poor } \\
> & \text { RBI do not want inflation } \\
> & \text { FDI reduced } \\
> & \text { Political unrest, votes } \\
> & \text { Rupee FEV falls } \\
> & \text { Stock market price falls } \\
> & \text { Imports are more and exports reduced } \\
> & \text { WTO negations violated (price caps) } \\
> & \text { consumer affordability } \\
> & \text { Government and policy makers worry } \\
& \text { about inflation. } \\
> & \text { Market players are under high risk with } \\
& \text { volatility of prices. } \\
> & \text { major implications for poverty reduction } \\
> & \text { Food grain prices and poor food } \\
& \text { entitlement affects }\end{aligned}$ \\
\hline II & Price Crash/Deflation & $\begin{array}{l}>\text { farmer of price woes } \\
>\text { Farmers affected } \\
>\text { Debt crisis } \\
>\text { Suicides } \\
>\text { Agrarian crisis } \\
>\text { poverty trap, livelihood security trap, Debt } \\
\text { trap, Death trap } \\
>\text { decide the fate of agriculture and farmer }\end{array}$ & \\
\hline III & Government Role & $\begin{array}{l}\text { Schemes/ budget } \\
\text { programs/subsidies/ MSP to purden/ } \\
\text { farmers/ Universal Basic Income. }\end{array}$ & $\begin{array}{r}\text { Government } \\
\text { multistake-holdres }\end{array}$ \\
\hline IV & Policy Measures & 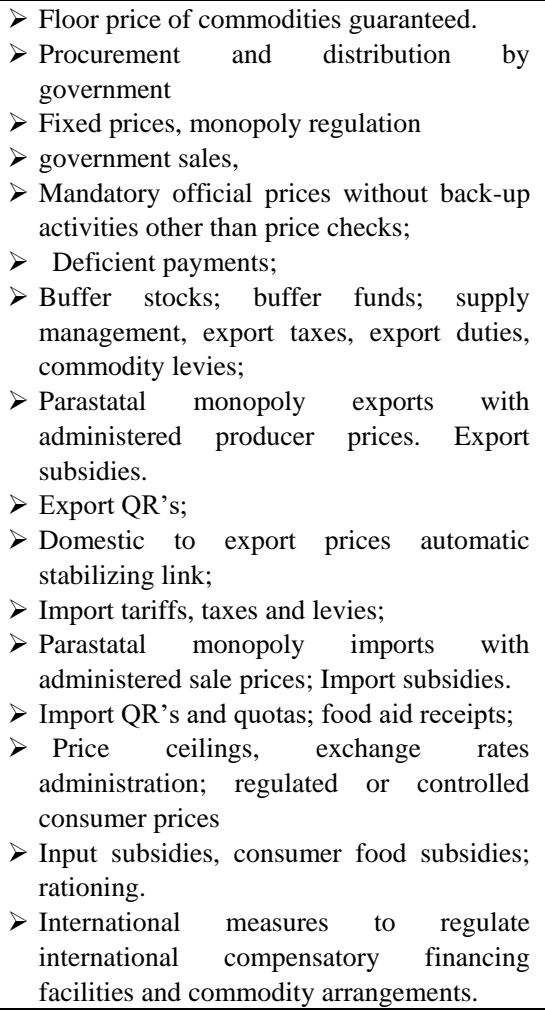 & \\
\hline VI. & $\begin{array}{l}\text { The reasons for price volatility in } \\
\text { LDC's. }\end{array}$ & \multicolumn{2}{|c|}{$\begin{array}{l}\text { Demand and supply, energy, fertilizer prices, production technologies, weather vagaries and } \\
\text { disasters, interest rates, insurance, public policies promotion and safety nets, political and } \\
\text { legislative factors, exchange rates, WTO, future markets, information friction, agricultural } \\
\text { supports, agricultural price \& trade policies, agricultural price transmission are responsible } \\
\text { price fluctuations }\end{array}$} \\
\hline
\end{tabular}

Author formulated the theory of agricultural price bubble and price crash and their effects on global economy 


\section{Conclusion}

A cob web model is inherent in agricultural price theory. Since 1950, many development economists and practitioners prophesy is that in LDC's low prices for agricultural commodities reduce poverty. Many countries are unable to make successful pricing policies in the absence of sound theoretical and methodological provision for decision-making. According to the economic theory of cooperativism, the entities come closer to the pecking order theory. Unexpected changes and Changes in regulations can have significant impact on the profitability of farming activities. "Demand channel" is the crucial factor in elucidation of commodity price growth. Future prices moments in agriculture have fat-tailed distributions and display quick and unpredicted price jumps.

International market volatility can transmit to the domestic economies and affect food grain prices and poor food entitlement. Global agricultural supports greatly affect world market prices. Cumulative prospect theory predicts farmer's coverage decisions accurately at $70 \%$ when insurance is framed as an investment. In agriculture marketing, farmers are price-takers. Producers receives more prices from middlemen when access to market price information available. The macroeconomic determinants of bubbles such as economic growth, money supply, and inflation have positive effects on price bubbles, and interest rates negatively affect the likelihood of bubbles.

World food markets chaos were causing by agricultural price and trade policies. In short run, in several countries, governments interventions based on empirical indicators rather than theoretical basis able to reduce volatility in domestic markets. Modelling in returns exactly highly risk due to agricultural price volatility for farmers as well as policy makers. The WTO analysis highlights the significance of strengthening multilateral disciplines on both import and export trade interventions to reduce beggar-thy-neighbor unilateral trade policy responses to food price fluctuations. And roughly half the observed regional price scattering is due to information frictions. In EU countries prevalence of land rents in modern agriculture causing long-lasting upward trend in agricultural land prices. Theory of NAFTA regionalism did not lead to regionalization and in turn not increasing share of intraregional international trade.

The study found that Agricultural prices are complex phenomena and effects on many sectors of the economy. It is a subject of hunger and contrasting to general economic principles. The price bubbles benefits farmers but it effects many multistake- holders like consumers, poor, BPL people, politicians, budget of the economy, WTO commitments, inflation, market players under risk, food entitlement and food security. Contrastingly, Price crash will effect farmers badly and force them to undergo deferent traps and commit suicide. It also leads to agrarian crisis in tropical countries. The government plays greater role to balance price crash by various schemes, programs, subsidies, MSP and by implementing UBI. It also protects farmers by various policies like different insurances, direct payments, cyclic payments, export and import subsidies etc.

The reasons for price volatility in international markets are namely, demand and supply, production technologies, energy, fertilizer prices, interest rates, weather vagaries and disasters, future markets, insurance, political and legislative factors, exchange rates, WTO, public policies promotion and safety nets. Policy makers and governments should design macroeconomic policies and execute precautionary government interferences to limit the likelihood of commodity price bubbles in commodity markets.

Agricultural commodities prices are complex phenomena and affected by numerous factors. Novelties in agricultural products fluctuations research offer scientific basis in planning of agricultural production. In economic theory, asymmetric price transmission has been the subject of considerable attention in agricultural gaps. Selection of forecasting models are based on chaos theory. Chaos in agricultural wholesale price data provides a good theoretical basis for selecting forecasting models. This theory can be applied to agricultural prices forecasting. Digital economy depends on price information and e-NAM markets in LDC's. Governments must focus on designing right price policy and foreign trade policy for crops. Focus must be on price signaling, price insurance and price loss coverage.

\section{References}

Adammer., P., \& Bohl, M. T. (2015). Speculative bubbles in agricultural prices. The Quarterly Review of Economics and Finance, 55, 67-76. https://doi.org/10.1016/j.qref.2014.06.003

Allen, T. (2014). Information Frictions in Trade. Econometrica, 82(6), 2041-2083. https://doi.org/10.3982/ECTA10984

Anderson, K. (2016). Antipodean agricultural and resource economics at 60: national and global price- and trade-distorting policies. Australian Journal of Agricultural and Resource Economics, 60(4), 614-628. https://doi.org/10.1111/1467-8489.12176

Can, M. (2008). The correlation between rising world food prices and market structure: the main reasons for prices increase in food market; the effects of price increase and its impact on Turkish economy. Maliye Dergisi, 155, $89-107$.

Chao, S., \& Jun, M. (Oct 10-11, 2009). "The study on chaotic identify of price index time series of agricultural products" 
paper presented at 2nd International Conference on Intelligent Computation Technology and Automation held at Changsha, Peoples R China. https://doi.org/10.1109/ICICTA.2009.798

Chaudhary, M. A., \& Qaisrani, A. A. (2002). Trade Instability, Investment and Economic Growth in Pakistan. Pakistan Economic and Social Review, 40(1), 57-73. Retrived from https://www.jstor.org/stable/25825236

Czyzewski, B., \& Brelik, A. (2014). Political rents in the European Union's Agriculture. Management-Poland, 18(2), 191-203. https://doi.org/10.2478/manment-2014-0051

Dastagiri, M. B., Jainuddin, S. M., \& Sweety, S. (2017). "Global Agricultural Aggregate Supports \& Measures During WTO Regime: Agriculture Development \& Promotion of Foreign Trade. Global Journal of Agricultural Research, 5(4),1-19. Retrived from https://www.eajournals.org/journals/global-journal-of-agricultural-research-gjar/vol-5-issue-4-november-2017/

Dastagiri, M. B. (2017). Global Agriculture: Vision and Approaches. European Scientific Journal, 13, 312-325, https://doi.org/10.19044/esj.2017.v13n21p312

Darnhofer, I., Bellon, S., Dedieu, B., \& Milestad, R. (2010). Adaptiveness to enhance the sustainability of farming systems. A review, Agronomy for Sustainable Development, 30(3), 545-555. https://doi.org/10.1051/agro/2009053

David, H. (2003). “Commodity Market Review 2003-2004,”. UNFAO Commodity and Trade Division, 3-18. Retrived from http://www.fao.org/3/a-y5117e.pdf

De Castro, E. R., \& Teixeira, E. C. (2012). Rural credit and agricultural supply in Brazil. Agricultural Economics, 43(3), 293-301. https://doi.org/10.1111/j.1574-0862.2012.00583.x

De Gorter, H., Drabik, D., \& David, R. J. (2013). How biofuels policies affect the level of grains and oilseed prices: theory, models and evidence. Global Food Security-Agriculture Policy Economics and Environment, 2(2), 82-88, https://doi.org/10.1016/j.gfs.2013.04.005

Dorward, A. (2013). Agricultural labour productivity, food prices and sustainable development impacts and indicators. Food Policy, 39, 40-50. https://doi.org/10.1016/j.foodpol.2012.12.003

Etienne, X. L., Irwin, S. H., \& Garcia, P. (2015). Price Explosiveness, Speculation, and Grain Futures Prices. American Journal of Agricultural Economics, 97(1), 65-87. https://doi.org/10.1093/ajae/aau069

Gilbert, C. L., \& Pfuderer, S. (2014). The role of index trading in price formation in the grains and oilseeds markets. Journal of Agricultural Economics, 65(2), 303-322. https://doi.org/10.1111/1477-9552.12068

Giri et.al, (2011) Impact of W.T.O on Indian Agriculture: Performance and prospects. International Journal of Current Research, 3(10), 066-070. Retrieved from http://www.journalcra.com

Glezakos, C. (1973). Export instability and economic growth: a statistical verification. Economic Development and Cultural Change, 21(4), 670-678. https://doi.org/10.1086/450669

Ghosray, A. (2008). Asymmetric adjustment of rice exports prices: the case of Thailand and Vietnam. Int. J. Applied Economics. 5(2), 80-91.

Gong, X., Sriboonchitta, S., Rahman, S., \& Kuson, S. (2015). Modeling value at risk of agricultural crops using Extreme Value theory. Advanced Science Letters, 21(5), 1339-1343. https://doi.org/10.1166/asl.2015.6025

Graubner, M., Balmann, A., \& Sexton, R. J. (2011). Spatial price discrimination in agricultural product procurement markets: A computational economics approach. American Journal of Agricultural Economics, 93(4), 949-967, https://doi.org/10.1093/ajae/aar035

Hajdukiewicz, A. (2014). European Union agri-food quality schemes for the protection and promotion of geographical indications and traditional specialties: An economic perspective. Folia Horticulture, 26(1), 3-17, https://doi.org/10.2478/fhort-2014-0001

Hertel and Winters. (2010). "Poverty \& the WTO impacts of the Doha development agenda," Washington, DC: World Bank. Retrived from http://documents.worldbank.org/curated/en/167341468742895197/Poverty-and-the-WTO-impacts-of-the-Doha-de velopment-agenda

Isgin, T., Forster, D. L. (2006). A hedonic price analysis of farmland option premiums under urban influence. Canadian Journal of Agricultural Economics-Revue Canadienne D Agroeconomie, 54(3), 327-340. https://doi.org/10.1111/j.1744-7976.2006.00053.x

Ivanic and Martin. (2008). Implications of higher global food prices for poverty in low-income countries. Agricultural Economics, 39(1), 405-416. https://doi.org/10.1111/j.1574-0862.2008.00347.x 
Koekebakker, S., \& Lien, G. (2004). Volatility and price jumps in agricultural future prices - Evidence from Wheat options. American Journal of Agricultural Economics, 86(4), 1018-1031. https://doi.org/10.1111/j.0002-9092.2004.00650.x

Landgraf, S., \& Chowdhury, A. (2015). Factoring emerging markets into the relationship between global liquidity and commodities. Journal of Economic Studies, 42(4), 622-640. https://doi.org/10.1108/JES-11-2013-0171

Li, J., Chavas, J. P., Etienne, X. L., \& Li, C. G. (2017). Commodity price bubbles and macroeconomics: evidence from the Chinese agricultural markets. Agricultural Economics, 48(6), 755-768. https://doi.org/10.1111/agec.12372

Li, J., Li, C. G., \& Chavas, J. P. (2017). Food price bubbles and government intervention: is china different? Canadian Journal of Agricultural Economics-Revue Canadienne D Agroeconomies, 65(1), 135-157, https://doi.org/10.1111/cjag.12106

Lloyd, T. (2017). Forty Years of Price Transmission Research in the Food Industry: Insights, Challenges and Prospects. Journal of Agricultural Economics, 68(1), 3-21. https://doi.org/10.1111/1477-9552.12205

Luckstead, J., \& Devadoss, S. (2019). Implications of commodity programs and crop insurance policies for wheat producers. Journal of Agricultural and Applied Economics, 51(2), 267-285. https://doi.org/10.1017/aae.2018.32

M. Ataman, A., \& John, C. B. (2006). Global Agricultural Trade And Developing Countries Dc. WORLD BANK, 2004, 5(2), 308-312. https://doi.org/10.1017/S1474745606232877

M.B. Dastagiri, Anjani, S. V. (2018). The Political Economy of Global Agriculture: Effects on Agriculture, Farmers, Consumers and Economic Growth. European Scientific Journal, 14(10). https://doi.org/10.19044/esj.2018.v14n4p193

Mateos-Ronco, A., Guzman, A. S. (2018). Determinants of financing decisions and management implications: Evidence from Spanish Agricultural Cooperatives. International Food and Agribusiness Management Review, 21(6), 701-721. https://doi.org/10.22434/IFAMR2016.0178

Meyer, J., \& Cramon, T. S. (2004). ASYMMETRIC PRICE TRANSMISSION: A SURVEY. Journal of Agricultural Economics, 55(3), 581-611. https://doi.org/10.1111/j.1477-9552.2004.tb00116.x

Miljkovic, D., \& Paul, R. (2003). Agricultural Trade in North America: Trade Creation, Regionalism and Regionalization. Australian Journal of Agricultural and Resource Economics, 47(3), 349-366, https://doi.org/10.1111/1467-8489.00218

Mitchell, T. (2017). Is knowledge power? information and switching costs in agricultural markets. American Journal of Agricultural Economics, 99(5), 1307-1326. https://doi.org/10.1093/ajae/aax035

Mitra, S., Boussard, J. M. (2012). A simple model of endogenous agricultural commodity price fluctuations with storage. Agricultural Economics, 43(1), 1-15. https://doi.org/10.1111/j.1574-0862.2011.00561.x

Novickyte, L. (2018). Income risk management in agriculture using financial support. European Journal of Sustainable Development, 7(4), 191-202. https://doi.org/10.14207/ejsd.2018.v7n4p191

Nureev, R. M., \& Petrakov, P. K. (2015). Doctrine of "fair price" by Thomas Aquinas: background, laws of development and specific interpretation. Journal of Institutional Studies, 7(1), 6-24.

https://doi.org/10.17835/2076-6297.2015.7.1.006-024

Palma, L., Dos, S. M. J., De Sousa, H. P. D., De Sousa, F. R. M., Verdete Da Silva, C., \& Maria, L. P. (2010). Attitudes of the Portuguese farmers to the EU common agricultural policy. Agricultural Economics-Zemedelska Ekonomika, 56(10), 460-469. https://doi.org/10.17221/123/2009-AGRICECON

Pieters, H., \& Swinnen, J. (2016). Trading-off volatility and distortions? food policy during price spikes. Food Policy, 61, 27-39. https://doi.org/10.1016/j.foodpol.2016.01.004

Ramesh, C. (2-5 February 2016). "Regional agricultural and trade policies: Indian perspective," Presented at the 60th AARES Annual Conference, Canberra, ACT. Retrieved from https://pdfs.semanticscholar.org/984f/9c87db84fa4b6f368feb3e684696a05bca3b.pdf

Rechka, K. (2018). Investigating market prices for agricultural production means and agricultural products. Baltic Journal of Economic Studies, 4(3), 244-253. https://doi.org/10.30525/2256-0742/2018-4-3-244-253

Rezitis, A. N., \& Stavropoulos, K. S. (2011). Price volatility and rational expectations in A Sectoral Framework Commodity Model: A Multivariate Garch Approach. Agricultural Economics, 42(3), 419-435. https://doi.org/10.1111/j.1574-0862.2010.00521.x

Ricci, E. C., Peri, M., \& Baldi, L. (2019). The effects of agricultural price instability on vertical price transmission: a 
study of the Wheat chain in Italy. Agricultural-Basel, 9(2). https://doi.org/10.3390/agriculture9020036

Satyanarayana, V., Wilson, W. W., Johnson, D. D., \& Dooley, F. J. (1998). Impacts of trade and agricultural policies on the world malt and malting barley market. Canadian Journal of Agricultural Economics-Revue Canadienne D Agroeconomie, 46(2), 127-147. https://doi.org/10.1111/j.1744-7976.1998.tb00359.x

Severova, L., \& Sredl, K. (SEP 14-15, 2010). Oligopoly competition on food market - Theory and Practice, presented at 19th International Scientific Conference on Agrarian Perspectives, Prague, CZECH REPUBLIC. Abstract retrieved from Agrarian Perspectives Series, 133-143.

Simonovska, A., Gjosevski, D., \& Campos, M. (2014). Effects of financial decisions on farm profitability in the republic of Macedonia: Evidence from a transition economy. Outlook On Agriculture, 43(4), 273-280, https://doi.org/10.5367/oa.2014.0185

Singh, K., \& Sangla, K. (2012). An Analysis of India's Exports (1991-2006). International Journal of Business Economics \& Management Research, 2, 79-108. Retrieved from http://www.zenithresearch.org.in

Su, X., Wang, Y., Duan, S. S., \& Ma J. H. (2014). Detecting chaos from agricultural product price time series. Entropy, 16(12), 6415-6433. https://doi.org/10.3390/e16126415

Thennakoon, J., \& Anderson, K. (2015). Could the proposed WTO special safeguard mechanism protect farmers from low international prices? Food Policy, 50, 106-113. https://doi.org/10.1016/j.foodpol.2014.10.014

Xie, C. P., Gao, J. F., Grant, J. H., \& Anders, S. (2018). Examining the Canada-China agri-food trade relationship: Firms, trading partners, and trading volumes. Canadian Journal of Agricultural Economics-Revue Canadienne D Agroeconomie, 66(4), 539-555. https://doi.org/10.1111/cjag.12172

Xie, H. L., \& Wang, B. H. (2017). An empirical analysis of the impact of agricultural product price fluctuations on China's grain yield. Sustainability, 9(6), 906. https://doi.org/10.3390/su9060906

Zafeiriou, E., \& Sariannidis, N. (2011). Nonlinearities in the price behaviour of agricultural products: The case of cotton. Journal of Food Agriculture \& Environment, 9(2), 551-555. Retrieved from

https://www.researchgate.net/publication/285875058_Nonlinearities_in_the_price_behaviour_of_agricultural_prod ucts_The_case_of_cotton.

Zambersky, P., \& Cajka, R. (2015). Taxation of exports - theory and practice. Agricultural Economics, 61(4), 158-165, https://doi.org/10.17221/219/2014-AGRICECON

\section{Copyrights}

Copyright for this article is retained by the author(s), with first publication rights granted to the journal.

This is an open-access article distributed under the terms and conditions of the Creative Commons Attribution license which permits unrestricted use, distribution, and reproduction in any medium, provided the original work is properly cited. 